Volume 6, Issue 3, 299 - 311.

ISSN: $2165-8714$

http://www.eu-jer.com/

\title{
Effect of Multimedia Assisted 7e Learning Model Applications on Academic Achievement and Retention in Students *
}

\author{
Hakan Sarac ** \\ MEB, TURKEY
}

\author{
Devrim Tarhan \\ Dumlupinar University, TURKEY
}

Received: May 10, 2017 - Revised: July 7, 2017 - Accepted: July 10, 2017

\begin{abstract}
In the rapidly developing age of technology, the contribution of using multimedia-supported instructional materials in the field of teaching technologies to science education has been increasing steadily. The purpose of this research is to compare the multimedia learning instructional materials prepared according to the 7E learning model and the students' academic success and the effect on the reminiscence of the learned knowledge in the science course described using traditional methods and models. In this research, a quadruple pattern of solomon was used as a semi-experimental design. As a data collection tool, the Matter's Change Unit Success Test was used. The research was conducted in fall semester of 2014-2015 academic year and on 92 fifth grade students. Experimental groups were given instructional materials prepared according to 7E model with multimedia support and control groups were taught with traditional method. There was no statistically significant difference in the pre-test scores of the experimental-1 and control-1 groups according to the independent t-test results in the applied success test but there was a statistically significant difference in favor of the experimental groups according to the post-test and retention test scores. According to the analyzed results; There is a statistically significant difference between the post-test and retention test scores of the experimental groups. There is also a statistically significant difference between the post-test and retention test scores of the control groups. But this difference is in favor of experimental groups. According to the results of the study, it can be said that the learning material prepared according to the multimedia supported 7E model influences the academic achievement positively and the learned information is more memorable.
\end{abstract}

Keywords: $7 E$ learning model, multimedia, science, matter and change.

To cite this article: Sarac, H., \& Tarhan, D. (2017). Effect of multimedia assisted 7e learning model applications on academic achievement and retention in students. European Journal of Educational Research, 6(3), 299-311. doi: 10.12973/eu-jer.6.3.299

\section{Introduction}

The use of technology in learning-teaching environments provides students with a richer learning environment, stimulates interest, provides lesson motivation and remembers information about the topic that they have learned previously (Oliver, 2000). Sonmez (2003), since it is possible to develop various kinds of materials to address more sensory organs by using technology, one of the important contributions of technology to education is that it is the preparation of effective course materials. Multimedia supported practices play an active role in the concrete conception of abstract concepts with more stimuli and lesson processing in science education. For this reason, it is emphasized that emphasis is given to the use of multimedia-supported applications in the science curriculum (Hashemzadeh \& Wilson, 2007). Accordingly, all kinds of visual and auditory information such as video-films, pictures, maps, sound recordings, computer animations and simulations can be used as a training material from applications with multimedia support (Weber \& Silk, 2007).

The use of visual and audial materials as multimedia-supported applications is undoubtedly of great importance when abstract concepts are taught in science education (Sonmez, 2003). It is stated that the use of technology in the constructivist learning approach is effective in developing high-order thinking skills including identifying problems, solving problems and producing appropriate solutions (Laney, 1990). Research has shown that science education can be learned from formal sources and that teachers who plan their lessons using informal sources such as written, audiovisual media, television programs, video-films can improve the learning quality of their students (Shaw \& Dybdahl, 2000).

\footnotetext{
* Acknowledgement: This research is a part of the doctoral dissertation completed in 2015 in the Institute of Educational Sciences of Dumlupinar University by the first author. It was also verbally presented in the International Conference on Best Practices and Innovations in Education (October 26-28, 2015, Club Hotel Grand Efe, Izmir, Turkey).
}

** Corresponding author:

Hakan Sarac, MEB, Turkey

Email: hknsrcmv@gmail.com 
Although the science curriculum revised by the Ministry of National Education in 2013 does not directly point out, it is based on the constructivist learning approach. Accordingly, the renewed science requires curriculum teachers to prepare and implement activities according to the "Research-inquiry based learning" approach that they will or will do at school (MEB, 2013). Research- inquiry based learning, is an approach that is based on the constructivist learning approach and is effective in the learning of learners and the development of high-level thinking skills (Minner, Levy \& Century, 2009). Research-inquiry based learning is student-centered approach. Research-inquiry based learning is an approach that identifies the student with the topic, which leads to finding solutions to the questions and to meaningful learning. Students feel active in their research-inquiry based learning process by asking questions, making explanations, making observations, doing observational research, taking individual responsibility, taking responsibility for learning and using various ways of communication, and this approach helps the student to evaluate the overall process (Davis, 2005).

The constructivist learning approach also supports cooperative learning and work. This allows the learners to take an active role in the learning process in cooperation with each other and to find solutions together by enabling them to see the problems they face from different perspectives (Alesandrini \& Larson, 2002). In a constructivist learning approach environment, the teacher encourages the student with guidance of the student, encourages the student to think critically, and assists in reaching the upper levels of cognitive goals such as analysis, synthesis during learning (YanparSahin, 2001). A constructivist teacher needs to work on the provision of concept development, in-depth learning, and the creation of a dynamic learning cycle, rather than treating goals, behaviors, and skills as objectives (Brooks \& Brooks, 1993; Holt-Reynolds, 2000; Zahorik, 1995). Various models are proposed for the use of the constructivist learning approach in science teaching, which exploits students' previous experiences and preliminary knowledge to make sense of new situations and assimilate them. These models are 3-stage model, 4E model, 5E model and 7E model (Kanli, 2009). 7E learning model The 5E learning model is an improved version (Bybee, 2003; Eisenkraft, 2003). The 7E learning model stages developed by Eisenkraft were taken into account in the research. These steps areelicit, engage, explore, explain, elaborate, evaluate, and extend (Eisenkraft, 2003; Kanli, 2009).

In the science teaching field of the 7E learning model; Many studies have been made on the effect of the students on the learning products, the contribution to the teaching material development process, the interest in the lesson, the skills and attitudes. Avcioglu (2015), in the his study titled "Investigation of the Effect of 7E Model on Success in Newton's Laws in High School 2 Physics Course", it was aimed to determine the students' achievement at the end of the course and preparation of activities and worksheets according to 7E Model in Newton Laws in high school 2 physics class. In the results of working, it was determined that there is a meaningful difference between Newton's Laws in accordance with the 7E Model and the course that is processed according to the method of straight expression, and it gives superiority to the student's achievement. Sadoglu and Akdeniz (2015) studied the development of student and teacher course materials in accordance with the 7E learning model for the subjects of the Black Body, Photoelectric Event and Compton Event in the Modern Physics Unit of the students and examined the effect of these materials on student success. In the study, the result of the 7E learning model was that the students' success levels were positively affected. Yenice (2014), in her graduate study, she investigated the effect of the 7E learning ring model on the academic achievement of the "Mitosis and Meiosis Division" students of the 8th grade students of secondary school and the persistence of the information they received. As a result of the research, it has been found that the processing of "Mitosis and Meiosis Division" with the activities and materials based on the 7E learning ring model has made a meaningful contribution to the academic achievement and the knowledge persistence of the students. Tas (2013) investigated the effect of cartoon-supported science teaching based on the 7E learning ring model on the success, knowledge persistence and student views in the elementary school students in our Life Electrical Unit. As a result of the research, it was determined that the students in the experimental group were more successful than the students in the control group.

Gurbuz (2012) in his Ph.D. study, he examined the effect of the 7E learning ring model on the course work, academic achievement and persistence of knowledge in the 6th grade Science and Technology course "Electricity in our Life". In the scope of the research, the material was developed according to the 7E learning ring model in the experimental group and the teaching methods based on the textbook were taken into consideration in the control group. As a result of the data analysis; It has been determined that the materials prepared by considering the 7E learning ring model increase the academic success and provide the permanence of the information. Polyiem, Nuangchalerm and Wongchantra (2011) compared the effect of the 7E learning ring model on the students' academic achievement on "inheritance" and the development of scientific process skills with the socio-scientific topic-based learning approach. As a result of the study, it was stated that the students based on the 7E learning ring model positively affected the academic achievements of the "inheritance" and the development of the scientific process skills. Demirezen (2010) in his Ph.D. study, he studied the effect of the 7E learning ring model on success, scientific process skills, and persistence of knowledge in simple electrical circuits. As a result of the research, it has been seen that the 7E learning ring model has contributed significantly to the achievement of the students, the elimination of conceptual misconceptions and the development of scientific process skills. Siribunnam and Tayraukham (2009) compared the effect of the 7E learning ring model, the KWL learning method, and the traditional teaching method on students' analytical thinking skills, 
academic achievement and attitudes in their chemistry work. As a result of the study, it has been stated that teaching based on the 7E learning ring model is more effective in increasing analytical thinking skills, academic achievements and attitudes towards the course than traditional teaching.

Multimedia supported applications emerge in researches that make it easier for students to draw attention to the lesson, to make the lessons fun, to reinforce the learning, to develop the positive interest in the lesson and to make the learned information permanent (Asci, 2006). Therefore, research is important in terms of the subjects related to the science curriculum and how the abstract concepts in these topics affect the academic achievement levels of the students and the remembrance of the learned information.

For each concept in the study, pictures, experimental activity drawings, computer animations and simulations and video-films were used together in the teaching-learning process from the multimedia supported teaching materials prepared according to the 7E learning model for each concept. It was aimed to determine the effect of using multimedia supported applications prepared according to the constructive approach 7E learning model in research, academic achievement in students' science achievement and persistence of learned information. Multimedia supported teaching materials were prepared according to the curriculum for each stage of the 7E learning model in the research. Teacher lesson is taught using these instructional materials.

\section{Purpose of the Research}

The aim of this research is to determine the students' academic achievement and the perceived persistence of the learned information as the result of course processing with the multimedia supported teaching materials prepared according to the 7E learning model of the 5th grade science course of secondary school.

\section{Research Question}

Is there any effect of multimedia supported instructional materials prepared according to 7E learning model on academic achievement and persistence of learned information in science course "Matter's Change Unit" of 5th grade students of secondary school?

\section{Model of Research}

\section{Method}

The research is quantitative and experimental design. In the study, four groups of solomon design were used in order to determine the effectiveness of two different teaching methods. In the four groups of solomon patterns, four groups, two of which are experimental and two of which are control groups, must be considered (Karasar, 2009). Because of the solomon pattern firstly, the classes that the same teacher entered in each of the four groups were determined before the experimental process. Later experiment and control groups were randomly selected among the detected classes. During the research, only one of the experimental and control groups determined according to the four groups of solomon design was pre-tested and at the end of the study, both the test and control groups were subjected to post-test and permanence test. Experiment-1 and control-1 groups pre-tested were also randomly selected. The symbolic appearance of the four groups of solomon patterns used in the research is shown in Table 1.

Table 1. Research Design

\begin{tabular}{|c|c|c|c|c|c|}
\hline Groups & Randon & Pre-test & $\begin{array}{l}\text { Experimental } \\
\text { Application }\end{array}$ & Post-test & $\begin{array}{l}\text { Retention } \\
\text { Test }\end{array}$ \\
\hline Experiment-1 & $\mathrm{R}$ & MCU-ST & $\begin{array}{l}\text { Multimedia supported } \\
\text { teaching materials }\end{array}$ & MCU-ST & MCU-ST \\
\hline Experiment-2 & $\mathrm{R}$ & - & $\begin{array}{l}\text { prepared according to } 7 \mathrm{E} \\
\text { learning model }\end{array}$ & MCU-ST & MCU-ST \\
\hline Control-1 & $\mathrm{R}$ & MCU-ST & Appropriate methods & MCU-ST & MCU-ST \\
\hline Control-2 & $\mathrm{R}$ & - & and models of curriculum & MCU-ST & MCU-ST \\
\hline
\end{tabular}

MCU-ST: Matter's Change Unit Success Test

R: Randon

In the study, MCU-ST was used as data collection tool for the dependent variables. Independent variables of the study, the effect on the experimental groups "Multimedia supported teaching materials prepared according to $7 E$ learning model" and the processing of the course with "Appropriate methods and models of curriculum" applied to the control groups.

\section{The sample of the study}

The study group of the study consists of 92 students in total, including two experimental groups and two control groups in the first semester of the academic year of 2014-2015, studying in the fifth class. The choice of experiment and 
control groups was random. There were 23 male and 23 female students in the experimental groups and 27 male and 19 female students in the control groups. Students are between 10 and 11 years old.

\section{Data Collection Tool}

The MCU-ST is a multiple-choice test consisting of 28 items that measure the academic achievement of students. The MCU-ST, 5th grade science course, has been developed to be suitable for the purpose of researching the test questions from Science courses and test books, taking into account student achievements. As a result of the analyzes made, the average strength of the test was calculated as .50 and the average discrimination strength was calculated as .49. According to these results, the difficulty level of the test is .50, so it can be said that it is ideal in terms of difficulty level. In terms of discrimination, the average value is greater than .40 , so the distinguishing characteristic can be expressed very well (Buyukozturk, 2012). The correlation (r), calculated as the confidence coefficient for the test, was calculated using the Kuder Richardson-20 method and the reliability of the test was found to be .71. The validity of the test of success was checked by two specialist field instructors and three science teachers in the field of science teaching.

\section{Experimental Application}

During the experimental study, the researcher participated in the experimental group as observers. Observation is a targeted look-and-see event to collect data on a specific person, event, object, place, condition and circumstances (Karasar, 2009). The observation in general is divided according to the active and passivity of the observations in itself. In the study, the researcher is a passive observer. In passive observation, the researcher only performs observing work, the identity of the researcher, the research topic, and the course of research are obvious (Libarkin \& Kurdzeil, 2002).

Experimental practice was 20 lesson hours, 4 hours per week and 5 weeks in total. The exams for the pre-test, post-test and retention test are outside of the experimental application time frame. The fifth grade "Matter's Change Unit" is divided into four main divisions. In the first section, "Matter's State of Change" six lesson hours have been reserved. In this section, the topics are processed in two parts in three parts as "Melting and Freezing", "Boiling, Evaporation and Chilling" and "Sublimation and Reding". In the second part, four lesson hours are reserved for the "Differentiating Features of Matter". In this section, the topics titled "Melting and Freezing Point" and "Boiling Point" are processed in two parts in two hours. In the third chapter "Heat and Temperature", four lesson hours are reserved. In this section, the topics titled "Heat and Temperature Concepts" and "Heat Exchange" are processed in two parts in two hours. Finally, in the fourth chapter, "How the Heat Affects the Facts" and six lessons are devoted to the subject. In this section, the topics are covered in two parts: "Expansion and Shrinkage in Solids", "Expansion and Shrinkage in Liquids" and "Expansion and Shrinkage in Gases". The teacher taught both experimental and control groups according to the above time schedule.

In the teaching process carried out in the experimental groups, the applications were made with multimedia supported instructional materials consisting of pictures prepared according to 7E model stages, experimental activity drawings, computer simulations and animations, video-film shootings and presentation files. In the control groups where the traditional teaching method is applied, Science Teacher conducts the course by acting with a good oral presentation about the unit. Course book, study book, teacher guide book and some other resources were used in the course. The teacher is asked to prepare for the lesson before the students enter the class. The teacher has taught the lecture straight. After each lesson, the teacher gave homework to the students for the next lesson and tried to reinforce the learning of the students. Experiments related to the unit were performed by the teacher in demonstration form. At the end of the unit, the teacher gave the evaluation questions at the end of the course book as homework.

\section{Data Analysis}

The appropriateness of the normal distribution of the pre-test, post-test and retention test results on the experimental and control groups in MCU-ST form applications was examined. For this, the statistical values and the skewness coefficient values of your data are taken into consideration. As a result, it has been found that the normal distribution of all test averages is appropriate. Independent groups t-test, dependent groups-t test, and dependent sample-repeat measures one-way ANOVA were analyzed in this research.

In addition, the effect sizes of the analysis results are calculated as eta-squared $(\eta 2)$. The eta-square with the effect size index allows comments on how much of the change in test scores is dependent on the independent variable. The value of the eta-square, .01, .06, and .14 are interpreted as the small, medium, and large effect size, respectively, (Buyukozturk, 2012).

\section{Findings}

The pre-test, post-test and retention test scores of the groups for their normal distribution suitability are given by the number of participants $(\mathrm{N})$, the average of each test result $(\bar{X})$, standard deviation (Ss) values, z statistics and skewness coefficient (Sc) are shown in table 2. 
Table 2. Descriptive Statistics of Experimental and Control Groups

\begin{tabular}{lccccc}
\hline Groups-test & $\mathrm{N}$ & $\bar{X}$ & $\mathrm{Ss}$ & z statistics & Sc \\
\hline Experiment-1 Pre-test & 23 & 10.56 & 2.40 & $.821 / .481$ & 1.70 \\
Experiment-1 Post-test & 23 & 19.73 & 4.64 & $-.003 / .481$ & -.006 \\
Experiment-1 Retn-test & 23 & 19.60 & 4.67 & $-.219 / .481$ & -.45 \\
Experiment-2 Post-test & 23 & 17.26 & 6.25 & $-.193 / .481$ & -.40 \\
Experiment-2 Retn-test & 23 & 18.0 & 6.33 & $-.253 / .481$ & .52 \\
Control-1 Pre-test & 23 & 9.91 & 3.35 & $.533 / .481$ & $.187 / .481$ \\
Control-1 Post-test & 23 & 13.69 & 5.51 & $.059 / .481$ & .44 \\
Control-1 Retn-test & 23 & 14.17 & 6.16 & $.356 / .481$ & .12 \\
Control-2 Post-test & 23 & 13.21 & 5.78 & $.588 / .481$ & .74 \\
Control-2 Retn-test & 23 & 14.78 & 5.23 & & 1.22 \\
\hline
\end{tabular}

Normal distribution is considered to be appropriate since skewness coefficient indicates that there is no significant difference from normal distribution at \pm 1.96 (Field, 2013). According to the table 2; The normal distribution was accepted as appropriate because the experimental-1 group was in the range of pre-test (1.70), post-test (-.006), retention test $(-.45) \pm 1.96$. The normal distribution was accepted as appropriate because the experimental-2 group was in the range of post-test $(-.40)$ and retention test $(.52) \pm 1.96$. According to the table 2 ; The normal distribution was accepted as appropriate because the control-1 group was in the range of pre-test (1.10), post-test (.44), retention test $(.12) \pm 1.96$. The normal distribution was accepted as appropriate because the control-2 group was in the range of posttest $(.74)$ and retention test $(1.22) \pm 1.96$.

Pre-test results for experimental-1 and control-1 groups before administration and independent groups t-test comparison are shown in Table 3.

Table 3. Experimental-1 and Control-1 Pre-test, $t$-Test Comparison

\begin{tabular}{lcccccc}
\hline Group/Pre-test & $\mathrm{N}$ & $\bar{X}$ & $\mathrm{Ss}$ & $\mathrm{t}$ & $\mathrm{sd}$ & $\mathrm{p}$ \\
\hline Experiment-1 & 23 & 10.56 & 2.40 & & & .45 \\
Control-1 & 23 & 9.91 & 3.35 & .757 & & 44 \\
\hline
\end{tabular}

According to table 3, pre-test average of experiment-1 group is 10.56, pre-test average of control-1 group is 9.91. There was no statistically significant difference between these two groups before application, $\left(\mathrm{t}_{(44)}=.757, \mathrm{p}>.05\right)$. Accordingly, it can be said that the groups of experiment-1 and control-1 are initially equal in terms of their academic successes.

The post-test results for the experimental and control groups after the administration and the independent groups $\mathrm{t}$ test comparison are shown in Table 4.

Table 4. Experimental and Control Groups Post-test Results t-Test Comparison

\begin{tabular}{|c|c|c|c|c|c|c|c|}
\hline Groups/Post-test & $\mathrm{N}$ & $\bar{X}$ & SS & $\mathrm{t}$ & SD & $\mathrm{p}^{*}$ & Effect size $(\eta 2)$ \\
\hline Experiment-1 & 23 & 19.73 & 4.64 & \multirow{2}{*}{1.526} & \multirow{2}{*}{44} & \multirow{2}{*}{.134} & \multirow{2}{*}{-} \\
\hline Experiment-2 & 23 & 17.26 & 6.25 & & & & \\
\hline Experiment-1 & 23 & 19.73 & 4.64 & \multirow{2}{*}{4.021} & \multirow{2}{*}{44} & \multirow{2}{*}{.000} & \multirow{2}{*}{.27} \\
\hline Control-1 & 23 & 13.69 & 5.51 & & & & \\
\hline Experiment-1 & 23 & 19.73 & 4.64 & \multirow{2}{*}{4.217} & \multirow{2}{*}{44} & \multirow{2}{*}{.000} & \multirow{2}{*}{.29} \\
\hline Control-2 & 23 & 13.21 & 5.78 & & & & \\
\hline Experiment-2 & 23 & 17.26 & 6.25 & \multirow{2}{*}{2.050} & \multirow{2}{*}{44} & \multirow{2}{*}{.046} & \multirow{2}{*}{.09} \\
\hline Control-1 & 23 & 13.69 & 5.51 & & & & \\
\hline Experiment-2 & 23 & 17.26 & 6.25 & \multirow{2}{*}{2.276} & \multirow{2}{*}{44} & \multirow{2}{*}{.028} & \multirow{2}{*}{.11} \\
\hline Control-2 & 23 & 13.21 & 5.78 & & & & \\
\hline Control-1 & 23 & 13.69 & 5.51 & \multirow{2}{*}{.526} & \multirow{2}{*}{44} & \multirow{2}{*}{.775} & \multirow{2}{*}{-} \\
\hline Control-2 & 23 & 13.21 & 5.78 & & & & \\
\hline
\end{tabular}

${ }^{* \mathrm{p}<.05}$

When the data in table 4 are examined, the post-test averages of experiment- 1 group are 19.73 and the post-test averages of experiment-2 group is 17.26 . Accordingly, there is no statistically significant difference in the post-test averages between the experimental groups, $\left(\mathrm{t}_{(44)}=1.526, \mathrm{p}>.05\right)$. Experiment-1 group's post-test average is 19.73 , 
control-1 group's post-test average is 13.69. Accordingly, there is a statistically significant difference between groups in favor of experiment-1 in terms of the post-test averages, $\left(\mathrm{t}_{(44)}=4.021, \mathrm{p}<.05\right)$. The effect size between the averages is .27. This means that $27 \%$ of the variance of the experiment- 1 group and the control-1 group post-test point averages were derived from the applications designed according to the applied multimedia supported 7E model. The post-test averages of the experiment- 1 group are 19.73, the control-2 group is the post-test average 13.21. Accordingly, there is a statistically significant difference between groups in favor of experiment- 1 in terms of the post-test averages, $\left(\mathrm{t}_{(44)}=\right.$ $4.217, \mathrm{p}<.05$ ). The effect size between the averages is .29. This means that $29 \%$ of the variance of the experiment- 1 group and the control-2 group post-test point averages were derived from the applications designed according to the applied multimedia supported 7E model.

When the data in table 4 are examined, the post-test averages of the experimental-2 group are 17.26 and the post-test averages of the control-1 group are 13.69. Accordingly, there is a statistically significant difference between groups in favor of experiment- 2 in terms of the post-test averages, $\left(\mathrm{t}_{(44)}=2.050, \mathrm{p}<.05\right)$. The effect size between the averages is .09 . This means that $9 \%$ of the variance of the experimental-2 group and the control-1 group post-test point averages were derived from the applications designed according to the applied multimedia supported 7E model. The post-test averages of the experimental-2 group are 17.26, thecontrol-2 group is the post-test average 13.21. Accordingly, there is a statistically significant difference between groups in favor of experiment- 2 in terms of the post-test averages, $\left(\mathrm{t}_{(44)}=\right.$ $2.276, \mathrm{p}<.05$ ). The effect size between the averages is .11. This means that $11 \%$ of the variance of the experimental-2 group and the control-2 group post-test point averages were derived from the applications designed according to the applied multimedia supported 7E model. The post-test averages of the control-1 group are 13.69, the control-2 group is the post-test average 13.21. Accordingly, there is no statistically significant difference between the control groups in terms of post-test averages, $\left(\mathrm{t}_{(44)}=.526, \mathrm{p}>.05\right)$.

The results of the retention-test on the experimental and control groups and the independent groups t-test were shown in Table 5 after five weeks of administration.

Table 5. Experimental and Control Groups Retention-test Results t-Test Comparison

\begin{tabular}{|c|c|c|c|c|c|c|c|}
\hline Group/Retention-test & $\mathrm{N}$ & $\bar{X}$ & Ss & $\mathrm{t}$ & $\mathrm{Sd}$ & $\mathrm{p}^{*}$ & Effect size $(\eta 2)$ \\
\hline Experiment-1 & 23 & 19.60 & 4.67 & \multirow[b]{2}{*}{.979} & \multirow[b]{2}{*}{44} & \multirow[b]{2}{*}{.333} & \multirow{2}{*}{ 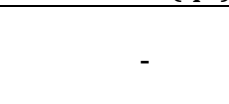 } \\
\hline Experiment-2 & 23 & 18.00 & 6.33 & & & & \\
\hline Experiment-1 & 23 & 19.60 & 4.67 & \multirow[b]{2}{*}{3.369} & \multirow[b]{2}{*}{44} & \multirow[b]{2}{*}{.002} & \multirow[b]{2}{*}{.20} \\
\hline Control-1 & 23 & 14.17 & 6.16 & & & & \\
\hline Experiment-1 & 23 & 19.60 & 4.67 & \multirow{2}{*}{3.298} & \multirow{2}{*}{44} & \multirow{2}{*}{.002} & \multirow{2}{*}{.20} \\
\hline Control-2 & 23 & 14.78 & 5.23 & & & & \\
\hline Experiment-2 & 23 & 18.00 & 6.33 & \multirow{2}{*}{2.076} & \multirow{2}{*}{44} & \multirow{2}{*}{.044} & \multirow{2}{*}{.09} \\
\hline Control-1 & 23 & 14.17 & 6.16 & & & & \\
\hline Experiment-2 & 23 & 18.00 & 6.33 & \multirow{2}{*}{1.878} & \multirow{2}{*}{44} & \multirow{2}{*}{.067} & \multirow{2}{*}{-} \\
\hline Control-2 & 23 & 14.78 & 5.23 & & & & \\
\hline Control-1 & 23 & 14.17 & 6.16 & \multirow{2}{*}{-.361} & \multirow{2}{*}{44} & \multirow{2}{*}{.720} & \multirow{2}{*}{-} \\
\hline Control-2 & 23 & 14.78 & 5.23 & & & & \\
\hline
\end{tabular}

${ }^{*} \mathrm{p}<.05$

When the data in table 5 are examined, the retention-test averages of experiment- 1 group are 19.60 and the retentiontest averages of experimental-2 group is 18.00. Accordingly, there is no statistically significant difference in the retention-test averages between the experimental groups, $\left(t{ }_{(44)}=.979, p>.05\right)$. Experimental-1 group's retention-test average is 19.60, control-1 group's post-test average is 14.17. Accordingly, there is a statistically significant difference between groups in favor of experiment- 1 in terms of the retention-test averages, $\left(\mathrm{t}_{(44)}=3.369\right.$, $\left.\mathrm{p}<.05\right)$. The retentiontest averages of the experiment- 1 group are 19.60, the control-2 group is the retention-test average 14.78. Accordingly, there is a statistically significant difference between groups in favor of experiment-1 in terms of the retention-test averages, $\left(\mathrm{t}_{(44)}=3.298, \mathrm{p}<.05\right)$. The effect sizes between the averages are .20 . These means that $20 \%$ of the variance of the experiment-1 group, the control-1 and the control-2 groups retention-test point averages were derived from the applications designed according to the applied multimedia supported 7E model.

When the data in table 5 are examined, the retention-test averages of the experimental-2 group are 18.00 and the retention-test averages of the control-1 group are 14.17. Accordingly, there is a statistically significant difference between groups in favor of experiment-2 in terms of the post-test averages, $\left(\mathrm{t}_{(44)}=2.076, \mathrm{p}<.05\right)$. The effect size between the averages is .09. This means that $9 \%$ of the variance of the experimental-2 group and the control- 1 group retention-test point averages were derived from the applications designed according to the applied multimedia supported 7E model. The retention-test averages of the experimental-2 group is 18.00, the control-2 group is the 
retention-test average 14.78. Accordingly, there is no statistically significant difference between the experimental-2 and control-2 groups in terms of retention-test averages, $\left(t_{(44)}=1.878, p>.05\right)$. The retention-test averages of the control-1 group are 14.17, the control-2 group is the retention-test average 14.78. Accordingly, there is no statistically significant difference between the control groups in terms of post-test averages, $\left(\mathrm{t}_{(44)}=-.361, \mathrm{p}>.05\right)$.

One-way ANOVA results for repeated measures of whether the mean of the pre-test, post test, and retention-test performed with the experimental-1 and control-1 groups differed significantly were shown in Table 6.

Table 6. ANOVA Results of All Test Scores in Experimental-1 and Control-1 Groups

\begin{tabular}{|c|c|c|c|c|c|c|c|}
\hline Groups & $\begin{array}{l}\text { Variance } \\
\text { Sources } \\
\end{array}$ & Sum of squares & $\begin{array}{c}\text { Degree of } \\
\text { freedom }\end{array}$ & $\begin{array}{l}\text { Squares } \\
\text { average }\end{array}$ & $\mathrm{F}$ & $\mathrm{p}^{*}$ & $\eta 2$ \\
\hline \multirow{3}{*}{ Experiment-1 } & $\begin{array}{l}\text { Measurement } \\
\text { (Described) }\end{array}$ & 1272.377 & 1.530 & 831.715 & \multirow{3}{*}{69.353} & \multirow{3}{*}{.000} & \multirow{3}{*}{.76} \\
\hline & $\begin{array}{l}\text { Error } \\
\text { (Unexplained) }\end{array}$ & 403.623 & 33.656 & 11.993 & & & \\
\hline & Total & 1676.000 & 35.186 & 843.708 & & & \\
\hline \multirow{3}{*}{ Control-1 } & $\begin{array}{l}\text { Measurement } \\
\text { (Described) }\end{array}$ & 250.638 & 2 & 125.319 & \multirow{3}{*}{22.783} & \multirow{3}{*}{.000} & \multirow{3}{*}{.51} \\
\hline & $\begin{array}{l}\text { Error } \\
\text { (Unexplained) }\end{array}$ & 242.029 & 44 & 5.501 & & & \\
\hline & Total & 492.667 & 46 & 130.820 & & & \\
\hline
\end{tabular}

$* \mathrm{p}<.05$

In table 6, there is a statistically significant difference between the test- 1 group pre-test and the post-test and retention test averages according to the result of the one-way ANOVA, $\left(\mathrm{F}_{(1.5-33.6)}=69.353, \mathrm{p}<.05\right)$. Also, the effect size between the average is .76. In this case, it can be said that $76 \%$ of the variance between the pre-test of the experimental- 1 group and the post-test and retention test point averages is derived from the applications designed according to the applied multimedia supported 7E model. There is a statistically significant difference between control-1 group pre-test and post-test and retention test averages according to one way ANOVA, $\left(\mathrm{F}_{(2-44)}=22.783\right.$, $\left.\mathrm{p}<.05\right)$. Also, the effect size between the averages is .51. This means that $51 \%$ of the variance between the control-1 group pre-test and post-test and retention test point averages is due to the method and techniques in the science curriculum applied by the teacher.

The post-test and retention-test results of the experimental-2 and control-2 groups the t-test of the dependent groups are shown in Table 7.

Table 7. Experimental-2 and Control-2 Groups t-Test Results

\begin{tabular}{|c|c|c|c|c|c|c|}
\hline Groups-test & $\mathrm{N}$ & $\bar{X}$ & Ss & $\mathrm{t}$ & sd & $\mathrm{p}$ \\
\hline Experiment-2 post-test & 23 & 17.26 & 6.25 & \multirow{2}{*}{-1.612} & \multirow{2}{*}{22} & \multirow{2}{*}{.121} \\
\hline Experiment- 2 retn-test & 23 & 18.00 & 6.33 & & & \\
\hline Control-2 post-test & 23 & 13.21 & 5.78 & \multirow{2}{*}{-.982} & \multirow{2}{*}{22} & \multirow{2}{*}{.337} \\
\hline Control-2 retn-test & 23 & 14.78 & 5.23 & & & \\
\hline
\end{tabular}

According to the data given in table 7, the post-test averages of the experimental-2 group are 17.26 and the retentiontest averages 18.00. There is no statistically significant difference in terms of mean scores of post-test and retentiontest of the students in experimental-2 group, $\left(\mathrm{t}_{(22)}=-1.612, \mathrm{p}>.05\right)$. The control-2 group had a post-test average of 13.21 and a retention-test average of 14.78 . There is no statistically significant difference between the control-2 group students in terms of post-test and retention-test point averages, $\left(\mathrm{t}_{(22)}=-.982, \mathrm{p}>.05\right)$.

\section{Discussion, Conclusions and Recommendations}

According to the findings obtained in MCU-ST application, when pre-test scores are examined in table 3, it is seen that there is no statistically significant difference between experiment- 1 and control-1 groups. At the same time, it is assumed that the experimental and control groups are similar in terms of achievement in the beginning of the researches that the average of the results of the written test results of the experimental and control groups are similar to each other, the students come from the same socio-cultural back ground and the students have studied at the same school during previous education years. When the findings in table 4 are examined, there is no statistically significant difference between the average of the experiment-1 group post-test scores and the average of the experiment- 2 posttest scores. However, there is a statistically significant difference between the averages of control-1 and control-2 posttest scores in favor of experiment-1 group. In addition, the independent variable is $27 \%$ and $29 \%$ of the dependent variable, which affects the post-test. It is seen that there is a statistically significant difference in favor of the 
experiment-2 group between the average of the post-test scores of control group-1 and the average of control- 2 group post-test scores. In addition, the magnitude of the independent variable influencing the dependent variable is $9 \%$ and $11 \%$. There was a difference in the magnitude of the effect between the control groups with the experiment-1 and experiment-2 groups, and this result was favored by experiment-1 group. For this reason, the solomon model may be pre-test for the experiment-1 group. There is no statistically significant difference between the averages of the post-test scores of the control groups.

According to the post-test results of the students in the experimental groups, the increase in the success levels and the magnitude of the effect between the averages are significantly higher than the increase in the success levels of the students in the control groups and the magnitude of the effect between the averages. According to this, it can be stated that with the multimedia supported teaching materials prepared according to 7E model, the course operator is effective in increasing the academic achievement of the students. The result is that in the literature, Avcioglu (2015), Demirezen, (2010), Gurbuz (2012), Polyiem, Nuangchalerm and Wongchantra (2011), Sadoglu and Akdeniz, (2015), Tas, (2013), Siribunnam and Tayraukham (2009) and Yenice (2014) are similar to the results that the materials developed in accordance with the 7E model effective in increasing the academic achievement of the students in their studies.

Five weeks after the end of the study, both the experiment and the control group were performed as MCU-ST retention test to the students. According to the results in table 5, there is no statistically significant difference between the average of the experiment- 1 retention test scores and the experiment- 2 retention test scores. However, there is a statistically significant difference between the mean of control-1 and control-2 retention test scores in favor of experiment-1 group. In addition, the size of the independent variable influences the retention test, which is the dependent variable, is $20 \%$. There is a statistically significant difference in favor of experiment- 2 group between the average score of experiment-2 group retention test score and the average score of control-1 group retention test scores. Moreover, the independent variable has a $9 \%$ influence on the dependent variable. There is no statistically significant difference between the retention test point averages of the control groups.

According to the retention test results of the students in the experimental groups, the increase in the success levels and the magnitude of the effect between the averages are significantly higher than the increase in the success levels of the students in the control groups and the magnitude of effect between the averages. According to this, it can be said that with the multimedia supported teaching materials prepared according to 7E model, the information obtained in the course processor and the increase in academic achievement are effective. The result is that in the literature, Avcioglu (2015), Demirezen, (2010), Gurbuz (2012), Tas, (2013) and Yenice (2014) are similar to the results that the materials developed in accordance with the 7E model are more effective for the students to keep the information they learn while they are working.

In table 6, ANOVA analysis between pretest, posttest and retention test of experiment-1 group revealed a statistically significant difference between the groups. In the Experiment- 1 group, the magnitude of the independent variable affecting the dependent variable was 76\%. The results of the Bonferroni comparison test to find out which groups are the difference are in favor of the post-test and the retention test. There is no statistically significant difference between the post-test and the retention test point averages of the experiment- 1 group. According to this result, the experiment 1 pre-test group can be considered as a separate group since the experiment-1 post-test and the retention test are equal to each other. ANOVA analysis between pre-test, post-test and retention test of control-1 group revealed statistically significant difference between the groups. The control-1 group has an independent variable, and the dependent variable has an effect size of 51\%. According to Bonferroni comparison test results, there is a statistically significant difference between control-1 group pre-test point averages and post-test, retention test point averages. These differences are in favor of the post-test and retention test. There is no statistically significant difference between control-1 group post-test and retention test point averages. According to this result, a control-1 pre-test group can be considered as a separate group since the control-1 post-test and retention test are equal.

According to table 7 , there is no statistically significant difference between the post-test and retention test point averages of the experiment- 2 and control-2 groups themselves. However, the post-test and retention test score averages of experiment-2 group, control-2 post-test and retention test scores are higher than average. According to this result, it can be said that the multimedia learning materials prepared according to the model 7E are better learned and learned information is more permanent.

\section{Recommendations of Research}

Based on the results of the research, the following can be suggested.

- Multimedia supported teaching materials prepared according to the 7E learning model and the processing of the course can be applied to other units of the Science course.

- Multimedia supported teaching materials prepared according to the 7E learning model can be applied to other courses where the course is particularly abstract. 
- Multimedia applications that enrich the use of multimedia-supported instructional materials prepared at each stage of the 7E learning model for the Science Teaching curriculum within Teaching Technologies can be designed.

\section{References}

Alesandrini, K., \& Larson, L. (2002). Teachers bridge to constructivism. ClearingHouse, 75 (3), 118-122.

Asci E. (2006). Televizyondaki Cizgi ve Animasyon Karakterlerin Farkli Yerlesim Yerlerinde Yasayan Cocuklarin Tuketici Davranislarina Etkisinin Incelenmesi [The Determination Of The Effects Of Cartoon Characters On Tv On Consumer Behavior Of Children Living In Different Settlement Areas]. (Yayinlanmamis Yuksek Lisans Tezi). Ankara Universitesi, Ankara

Avcioglu, O. (2015). Investigation of the effects of 7e model on success, in the subject of newton laws of second grade high school students' physics classes (Master Thesis). Gazi University, Ankara, Turkey.

Brooks, J. G., \& M.G. Brooks. (1993). The case for constructivist classrooms. Alexandria, VA: Association for Supervision and Curriculum Devolopment.

Buyukozturk, S. (2012). Sosyal bilimler icin veri analizi el kitabi [Data analysis handbook for social sciences]. Ankara. Pegem A Yayincilik.

Bybee, R.W. (2003). Achieving scientific literacy: From purposes topractices. Portsmouth, UK: Heinemann.

Davis, S.A. (2005). Inquiry-Based Learning Templates For Creating Online Educational Paths. Master of Science, Texas, A\&M University.

Demirezen, S. (2010). The effect of 7e model to students achievement, development of scientific process skills, conceptual achievement and retention levels in electrical circuits subject (Doctoral dissertation). Gazi University, Ankara, Turkey.

Eisenkraft, A. (2003). Expanding the 5e model. TheScienceTeacher, 70 (6), 56-59.

Field, A. (2013). Discovering statistics using IBM SPSS statistics paperback-Picture book. Sage.

Gurbuz, F. (2012). 7E ogrenme modelinin 6. sinif fen ve teknoloji dersi "yasamimizdaki elektrik" unitesinde ogrencilerin akademik basarilarina ve kaliciliga etkisi [The Effect of 7E Learning Model on Academic Achievements and Retention of Students in The Unit of "Electricity in Our Life" 6 th Grade Science and Technology Course]. (Yayinlanmamis doktora tezi). Ataturk Universitesi Egitim Bilimleri Enstitusu, Erzurum.

Hashemzadeh, N., \& Wilson, L. (2007). Teaching with the lights out: what do were ally know about the impact of technology intensive instruction? College Student Journal, 41(3), 601-612.

Holt-Reynolds, D. (2000). What Does The Teacher Do? Constructivist Pedagogies And Prospective Teachers' Beliefs About The Role of a Teacher, Teaching and Teacher Education, 16, 21-32.

Kanli, U. (2009). Yapilandirmaci kuramin isiginda ogrenme halkasinin kokleri ve evrimi: Ornek bir etkinlik [Roots and Evolution of Learning Cycle Model in Light of Constructivist Theory-A Sample Activity]. Egitim ve Bilim Dergisi, 34(151), 44-64.

Karasar, N. (2009). Bilimsel arastirma yontemi [Scientific research method]. Ankara: Nobel Yayin Dagitim.

Laney, D. (1990). Micro computers and social studies. OCSS Rewiev, 26, 3037.

Libarkin, J. C., \& Kurdziel, J. P., (2002). Research methodologies in science education: Qualitative data. Journal of Geoscience Education, 50, 2, 195-200

MEB. (2013). Ilkogretim kurumlari (ilkokullar ve ortaokullar) fen bilimleri dersi (3, 4, 5, 6, 7 ve 8. siniflar) ogretim programi

[Primary education institutions (elementary schools and junior high schools) science curriculum (3, 4, 5, 6, 7 and 8 classes) curriculum]. Ankara: MEB Yayinevi

Minner, D. D., Levy, A. J., \& Century, J. (2009). Inquiry-based science instruction. What is it and does it matter? Results from a research synthesis years 1984 to 2002. Journal of Research in Science Teaching, 47(4), 474-496.

Murat, T. A. S. (2013). Karikatur Destekli Ogretimin Ogrenci Akademik Basarisi ve Bilginin Kaliciligina Olan Etkisinin Arastirilmasi [A Research on Science Teaching Aided Cartoons: Is an Example Lives of Electrical Unit Primary 6th Class]. Uludag Universitesi Egitim Fakultesi Dergisi, 26(2).

Oliver, K.M. (2000), Methods for developing constructivist learning on the web. Educational Technology,40 (6), 5-17. 
Polyiem, T., Nuangchalerm, P., \& Wongchantra, P. (2011). Learning achievement, science process skills, and moral reasoning of ninth grade students leaned by 7 e learning cycle and socioscientific issue-based learning. Australian Journal of Basic and Applied Sciences, 5(10), 257-564.

Shaw, D. G., \& Dybdahl, C. S. (2000). Science and the popular media. Science activities: Classroom projects and curriculum ideas,37 (2), 22-31.

Siribunnam, R., \& Tayraukham, S. (2009). Effects of 7-E, KWL and conventional instruction on analytical thinking, learning achievement and attitudes toward chemistry learning. Journal of Social Sciences, 5(4), 279-282.

Sonmez, V. (Ed). (2003). Ogretmenlik meslegine giris [Introduction to teaching profession]. Ankara: Ani Yayincilik.

Sadoglu, G. P., \& Akdeniz, A. R. (2015). 7e Ogrenme Modeline Yonelik Tasarlanan Materyallerin Lise Ogrencilerinin Modern Fizik Basarilarina Etkisi [Effect of Designed Materials According to 7E Learning Model on Success of High School Students in Modern Physics]. Journal of Computer and Education Research (ISSN: 2148-2896), 3(5), 96-129.

Weber, C. M., \& Silk, H. (2007). Movies and medicine: An electiveusing film toreflect on thepatient, family, andillness. Family Medicine, 39 (5), 317-319.

Yanpar-Sahin, T. (2001). Olusturmaci yaklasimin sosyal bilgiler dersinde bilissel ve duyussal ogrenmeye etkisi [The Effect of Constructivist Approach on Cognitive and Affective Learning in Social Studies Course]. Kuram ve Uygulamada Egitim Bilimleri Dergisi, 1(2), 465-481.

Yenice, E. (2014). Yapilandirmaci yaklasimin 7e ogrenme modelinin 8. sinif fen ve teknoloji dersi "mitoz ve mayoz bolunme" konusunda ogrencilerin akademik basarilarina etkisinin incelenmesi [Researching the effect of 7E learning model of constructivist approach on students' academic success on the topic of "Mitosis and Meiosis Division" at 8th grade science and technology class]. (Yuksek lisans tezi). Kafkas University, Kars

Zahorik, J. A. (1995). Constructivist Teaching Bloomington: Phi Delta Kappa Educational Foundations. 